\title{
Taking the Sector Seriously: Data, Developments, and Drivers of Intrasectoral Earnings Inequality
}

\author{
Stefan Thewissen $^{1}$ (D) Olaf van Vliet $^{2}\left(\right.$ D $\cdot$ Chen Wang $^{3}$
}

Accepted: 16 June 2017/ Published online: 4 July 2017

(C) The Author(s) 2017. This article is an open access publication

\begin{abstract}
The widespread increase in earnings inequality within postindustrial countries has received a lot of attention in both the public debate and the academic literature. Remarkably, the developments in earnings inequality have mainly been studied at the country level, whereas there is substantial variation across sectors within countries. This study explores the developments and the drivers of earnings inequality at the sectoral level. From an empirical perspective, this study aims to contribute to the inequality literature by analyzing measures of sectoral earnings inequality. The study relies on newly assembled data based on Luxembourg Income Study micro data for eleven sectors across eight countries over the past few decades. As a theoretical contribution, the study examines the three key explanations for increasing earnings inequality that have been debated and analysed by economists, sociologists and political scientists-namely, globalisation, technological change and waning labour union power-but this time with sectoral earnings inequality data. Interestingly, the results provide only limited support for the argument that international trade leads to higher levels of earnings inequality. When we focus the analysis on trade with less developed countries we find a positive association between trade and earnings inequality. With regard to technological change, our findings provide mixed evidence for the hypothesis that skill-biased technological change increases earnings inequality. Our results bring back the waning country-wide labour union power as an
\end{abstract}

Stefan Thewissen

stefan.thewissen@spi.ox.ac.uk

Olaf van Vliet

o.p.van.vliet@law.leidenuniv.nl

Chen Wang

wang.chen@mail.shufe.edu.cn

1 Department of Social Policy and Intervention, and Nuffield College, Institute for New Economic Thinking at the Oxford Martin School, University of Oxford, Oxford, UK

2 Department of Economics, Leiden University, Leiden, The Netherlands

3 School of Urban and Regional Science, Shanghai University of Finance and Economics, Shanghai, China 
important driver of earnings inequality. This corresponds with the fact that our sectoral data reveal a more general trend towards rising inequality across sectors over time.

Keywords Inequality · Wage bargaining - Globalisation · Technological change

\section{Introduction}

A widely observed phenomenon in social sciences is the gradual and widespread increase in earnings inequality within developed countries (Atkinson 2003; Alderson et al. 2005; Kenworthy and Pontusson 2005; Brandolini and Smeeding 2009; Immervoll and Richardson 2011; Gornick and Jäntti 2013; Iversen and Soskice 2013). Economists, sociologists, and political scientists generally put forward three explanations for this upsurge in inequality at the country level. The first two are increased international trade and technological change, which are both arguably disadvantageous to the low-skilled. The third line of explanations focuses on changes in labour market institutions, in particular weakening employment protection legislation and union power (e.g., Alderson and Nielsen 2002; Mahler 2004; Koeniger et al. 2007; Oliver 2008; OECD 2011a; Alderson and Doran 2013; Oesch 2013; Wren 2013; Swank 2015). Substantial attention has been paid to inequality trends at the country level, but there is a remarkable knowledge gap with regard to the developments within countries across different sectors. Some sectors are much more exposed to international economic integration or technological change than other sectors. Hence, it could be expected that sectors more exposed to these trends should have witnessed increased levels of inequality. On the other hand, a common trend in inequality levels across sectors within a country would provide evidence for country-level labour market institutions as an explanation for the surge in inequality.

The aim of this paper is to explore the developments and the drivers of sectoral earnings inequality across 11 sectors in 8 OECD countries. As such, this study seeks to make a number of mainly empirical contributions. First, we use newly assembled data on sectoral inequality based on Luxembourg Income Study (LIS) micro data (LIS 2013; Wang et al. 2014). ${ }^{1}$ This dataset, based on harmonised sector and earnings information, is available online. Second, compared to existing studies on earnings inequality in OECD countriesby and large country-level studies-a sectoral approach increases the number of observations substantially, which increases the leverage in pooled time-series cross-sectional regression analyses. Our third contribution relates to the few studies that examine possible determinants of rising inequality by means of a sectoral design in multiple countries over time (Mahler et al. 1999; OECD 2011a; Michaels et al. 2014). Whereas these three studies examine only one or two determinants of earnings inequality, our study includes all three variables that are highlighted in the debate on earnings inequality: international trade, skillbiased technological change and labour market institutions. For international trade, we make a distinction between trade in general and trade with less developed countries. A

${ }^{1}$ See also Thewissen et al. (2013). 
fourth and final contribution to these three studies is that these studies include two moments per sector at maximum. Utilizing our newly assembled data, we include multiple moments per sector which provide further insights in the developments in earnings inequality.

Our data show that there is substantial heterogeneity across sectors in levels of earnings inequality. Furthermore, the levels of sectoral earnings inequality have generally increased substantially over time. With regard to the drivers of these developments, the results provide only limited support for the argument that international trade is associated with higher levels of earnings inequality. When the analysis is focused on trade with less developed countries, we find a positive association between trade and earnings inequality. Furthermore, the results provide mixed evidence for the hypothesis that skill-biased technological change is positively related to sectoral earnings inequality. Our results point to waning trade union power at the country level as a driver of the general rise in sectoral earnings inequality. When fewer employees are covered by bargaining agreements, workers' wages tend to be more unequal.

\section{Literature and Hypotheses}

Three explanations for the widespread trend of increasing earnings inequality at the country-level are regularly put forward, namely, increasing international trade, skill-biased technological change, and weaker labour market institutions. Starting with the first; the amount of international trade increased substantially during the last decades, in particular between developed and developing countries (Harrison et al. 2011). Our theoretical understanding of the distributive effects of international trade is based on two standard models from international economics. In the Ricardo-Viner model, sectors are the central unit of analysis as it is assumed that factor mobility is limited. ${ }^{2}$ Employees in sectors with higher exports as a result of the reduction of trade restrictions benefit, whereas employees in sectors with increased imports loose (Samuelson 1971; Sirgy et al. 2007; Hays 2009; Walter 2010; Thewissen and Van Vliet 2015). In contrast, the Stolper-Samuelson model (1941) predicts that when countries engage into trade, the production factors that are relatively abundant gain. In developed countries, where high-skilled workers are relatively more abundant, engaging into trade will lead to a higher skill demand, whilst the lowskilled will suffer from the increased competition with developing countries with a relative abundance of low-skilled labour (Burgoon 2001). Hence, the hypothesis to be tested is that sectors more exposed to international trade experience higher levels of earnings inequality. This association can be expected to be stronger for trade with less developed countries.

A second prevalent explanation for increasing earnings inequality is skill-biased technological change (Goldin and Katz 2008; Oesch 2013; Wren 2013). Technological

\footnotetext{
${ }^{2}$ Limited mobility of employees between sectors can be a result of various labour market frictions, such as search costs in looking for jobs (Mortensen and Pissarides 1999), job and industry specific human capital (Estevez-Abe et al. 2001), or institutions such as employment protection legislation (Hellier and Chusseau 2013).
} 
innovation complements the high-skilled, whilst it substitutes routine labour by capital. The theory plays a central role in the wage literature, using skill demand or the skill wage gap as dependent variable. The wage literature reports evidence for skill-biased technological change leading to polarisation in the labour market, though the analyses are mainly limited to the US (e.g. Autor et al. 2003; Goldin and Katz 2008). In a study on the labour market effects of information and communication technologies (ICT), Michaels et al. (2014) extend this empirical evidence to sectors in Japan and nine European countries. We hypothesize that in sectors with more technological change, higher levels of earnings inequality can be observed.

A third line of explanations highlights changes in labour market institutions as the main cause of growing earnings dispersion in OECD countries. Wages and other working conditions are set in negotiations between employers and employees (Freeman 1991; Christensen and Wibbels 2013; Western and Rosenfeld 2011). The outcomes of these negotiations are largely determined by a country's institutional setting of labour relations and political power distributions (Kenworthy 2001; Martin and Swank 2012; Huber and Stephens 2014; Swank 2015). A first factor of relevance in this respect is the share of employees covered by wage bargaining agreements (Wallerstein 1999). When more employees are covered by bargaining agreements, the variation in workers' wages is smaller. Hence, we hypothesize that bargaining coverage is negatively associated with earnings inequality.

The level of wage coordination is a relevant factor in the wage setting as well. The central hypothesis put forward in the earnings inequality literature is that countries with centralised systems of wage bargaining have a more compressed wage distribution. The underlying argument is that centralised wage bargaining creates fewer and smaller wage differentials when more firms and industries are covered by the same wage settlements (Wallerstein 1999; Rueda and Pontusson 2000; Mahler 2004). Interestingly, the existing empirical evidence is based on country-level studies. Hence, it is an empirical question whether and how coordination is associated with sectoral earnings inequality.

Another institution that may affect labour market outcomes is employment protection legislation (EPL). As a result of EPL, the gap between employees with a permanent contract (insiders) and employees without a permanent contract (outsiders) becomes larger. Stricter EPL increases the costs of dismissal, which gives insiders bargaining power in wage setting (Lindbeck and Snower 2001; Rueda 2007). However, this effect crucially depends on the extent to which these costs can be shifted from employers onto workers (OECD 2011a: 153). Hence, following the OECD (2011a), it is theoretically hard to predict, and therefore an empirical question, how EPL is associated with earnings inequality.

Finally, the political colour of governments may have an impact on wage inequality. In the literature on wage inequality, two effects can be distinguished. First, since governments are widely involved in private-sector wage setting in many OECD countries, the political colour of governments may have a direct effect on wage inequality. In this respect, leftwing governments can be expected to pursue greater wage equality than conservative or liberal governments (Wallerstein 1999). A second argument, one that is more indirect, is that governments may influence wages and employment through institutions and policies such as minimum wage legislation, taxes, and other forms of income policies. Again, it may be expected that left-wing governments opt for policies that lead to less earnings inequality than conservative or liberal governments (Rueda and Pontusson 2000; Pontusson et al. 2002; Oliver 2008). 


\section{Data, Measures and Method}

\subsection{Sectoral Earnings Inequality}

To analyse patterns of the level of intrasectoral earnings inequality, we calculate the Gini coefficient. The Gini coefficient is the most frequently used inequality measure in the literature, and for our purposes it has useful characteristics. As we are calculating inequality within sectors, our sample becomes smaller. We can correct the Gini coefficient for underestimation bias resulting from relatively small samples by multiplying it by $\frac{n}{n-1}$, called the first order correction (Deltas 2003). ${ }^{3}$ We construct our dataset (Wang et al. 2014) on the basis of the Luxembourg Income Study (LIS) micro data (see also Gornick and Jäntti 2013), elaborating on Mahler et al. (1999) who calculate sectoral levels of earnings inequality for two LIS waves. We follow their choice to restrict the sample to individuals aged between 25 and 54, which are those people most dependent on earnings as source of income. Since we are interested in labour earnings inequality, we only include income from wages and salaries or self-employment, omitting income from other sources such as interest and rent, and we do not adjust the wages for taxes or social contributions. ${ }^{4} \mathrm{We}$ follow standard LIS top- and bottom coding conventions. We base our calculations on individual data.

We standardise all sectoral information in LIS following the ISIC 3.0 classification. As presented in Table 1, we distinguish between nine sectors at the two-digit level, and we further break down the manufacturing into eleven subsectors using the three-digit level, as in Mahler et al. (1999), OECD (2011a), and Michaels et al. (2014). ${ }^{5}$ Based on sectoral data availability, we have to restrict our analysis to eight OECD countries of five periods of around 5 years between 1984 and 2007. We can only use the LIS information up to and including 2007 as our indicator for technological change, which we will discuss in Sect. 3.2, is only available up to and including 2007. We do not include measures of intersectoral earnings inequality; these are beyond the scope of this paper.

\subsection{Independent Variables}

To examine the sectoral exposure to international trade we use the OECD STAN database (2011b) where we calculate trade values as the sum of sectoral imports and exports in percentage of sectoral added value. This dataset contains information on the value of traded goods in agriculture, mining, manufacturing and its sub industries, and the utilities

\footnotetext{
3 The first order corrected Gini is multiplied by 100 in the regressions to enhance readability of the coefficients in the tables.

4 We refer to our income definition as 'earnings', which corresponds to 'labour income' in the LIS template.

5 No further breakdown in the community services sector is possible with LIS micro data for a sufficient number of country-period observations. The community sector consists of people working in public administration, education, health and social work, and other community and personal service activities. We leave out total manufacturing; and manufacturing of chemical, rubber, plastics, and fuel products (23t25) in our descriptives and regressions to avoid having sectoral overlap, as we include all constituent sectors separately.
} 
sector. We use the OECD (2002) EBOPS Trade in services dataset to obtain information on the value of traded services for the services sectors. ${ }^{6}$

Unfortunately, with the OECD STAN (2011b) data no distinction is possible between trade among developed and trade between developed and developing countries. To collect data on trade with less developed countries, we use the OECD STAN Bilateral (2016) database instead. Again, we complement this with the OECD (2002) EBOPS Trade in Services dataset for the services sectors. Here, we calculate the sum of trade (imports and exports) coming from the BRIICS countries (Brazil, Russia, Indonesia, India, China, South Africa) and Mexico as a percentage of sectoral value added. ${ }^{7}$ For trade with developing countries, substantially fewer (39\%) observations are available.

To examine the association between skill-biased technological change and earnings inequality, we follow Michaels et al. (2014) and include ICT capital compensation as a share of sectoral value added from the EU-KLEMS dataset (2011). ${ }^{8}$ As already stated, for this sectoral indicator information is only available up to and including 2007. Empirically, skill-biased technological change is hard to measure (OECD 2011a)—which could possibly affect our results - but we use the best indicator that is currently available for the sectoral level.

To account for general economic conditions at the sectoral level, we include the natural logarithm of the volume of the gross sectoral value added from the EU-KLEMS dataset (2011).

Furthermore, the study examines a number of variables measuring labour market variables that are highlighted in the comparative political economy literature on earnings inequality (Wallerstein 1999; Rueda and Pontusson 2000; Mahler 2004; Oliver 2008). To account for wage-setting institutions, we include measures of the bargaining coverage rate

\footnotetext{
6 The correspondence table for NACE and EBOPS looks as follows:

$\mathrm{NACE}$

F. Construction

GtH. Wholesale...

I Transp...

JtK Finance...

LtQ Community...

EBOPS:

249 Construction services

236 Travel

205 Transportation and 245 Communication services

253 Insurance services, 260 Financial services, 262, Computer and information services, 266 Royalties and license fees, 268 Other business services

287 Personal, cultural, and recreational services, 291 Government services, n.i.e. We linearly interpolate the values of trade in services per country/sector to maximize the number of observations. Furthermore, for a number of observations we use data from the previous years. Leaving out the supplemented data does not affect any of our results, except that trade with developing countries becomes significant at the $1 \%$ instead of the $10 \%$.
}

7 We linearly interpolate the data. Leaving out the interpolated data does not affect the significance of trade from less developed countries in the regressions.

8 As Michaels et al. (2014) also note, since capital compensation is calculated as a residual, it could be negative. We replace values by zeros if negative (3\% of total observations). We calculate the indicator by multiplying ICT capital compensation as a share of total capital compensation by capital compensation, and divide this by value added, where we have placed capital compensation and value added in real dollars using OECD information on exchange rates. We have to use the EU-KLEMS March 2008 version for Portugal. 
Table 1 Country, period, and sector sample

\begin{tabular}{lll}
\hline Country & Period & Sectors (ISIC) \\
\hline 1. Czech Republic & 1996,2004 & AtB. Agriculture and fishing \\
2. Denmark & $1987,1992,1995,2000,2004,2007$ & C. Mining and quarrying \\
3. Finland & $1987,1991,1995,2000,2004,2007$ & D. Manufacturing \\
4. Germany & $1984,1989,1994,2000,2004,2007$ & 15t16. Man. food \\
5. Ireland & $1994-1996,2004,2007$ & 17t19. Man. textile \\
6. Sweden & $1987,1992,2000,2005$ & 20. Man. wood \\
7. UK & $1986,1999,2004,2007$ & 21t22. Man. paper \\
8. US & $1986,1991,1994,2000,2004,2007$ & 23t25. Man. chemicals \\
& & 26. Man. minerals \\
& & 27t28. Man. metals \\
& & 29t33. Man. machinery \\
& & 34t35. Man. transport \\
& & 36t37. Man. other \\
& & E. Utilities \\
& & F. Construction \\
& & GtH. Wholesale and hotels \\
& & I. Transport and telecommunications \\
& & JtK. Finance, real estate, business \\
& & LtQ. Community services
\end{tabular}

We combine the 1994-1996 waves for Ireland where we recalculate the earnings information to 1995 levels using information on inflation from the World Bank (2013)

and the level of wage coordination. The first one is measured as the proportion of employees covered by wage bargaining agreements. For the level of wage coordination, we use an index where a higher number indicates a more centralised level of wage coordination. ${ }^{9}$ Both measures are taken from the ICTWSS database (Visser 2013). ${ }^{10}$ The study accounts for a country's strictness of employment protection legislation, relying on OECD data (2009). To examine the effect of left-wing governments, we use the percentage of total cabinet posts held by left-wing parties from the Comparative Political Data Set (Armingeon et al. 2012).

Unfortunately, there is no pooled time-series cross-sectional data available for our labour market variables at the sectoral level. Arguably, labour market policies or institutions are generally set at the country level, even though there can be sectoral differences for instance in trade union influence. Evidence for labour market institutions affecting earnings inequality would come in our framework from a significant conditional correlation between a country-level labour market variable and a general trend in inequality levels across sectors within that country.

Last, to account for more general economic conditions at the country level, we include the unemployment rate. As low-skilled workers are more substitutable than high-skilled workers, the bargaining position of low-skilled workers is more directly and more

\footnotetext{
${ }^{9}$ For the level of wage coordination, there are five values, where the lowest (1) indicates fragmented wage bargaining, and the highest (5) centralised (informal or formal) bargaining by peak associations or monopolistic union confederations or influential large firms.

${ }^{10}$ For Ireland there are only 3 observations available for bargaining coverage in the fourth version of ICTWSS; the first observation is for 2000. We use the third ICTWSS version for this country and we interpolate the data. The correlation between the linearly interpolated series from the third and fourth version for the 9 overlapping observations is 0.89 .
} 
disadvantageously affected by unemployment (Pontusson et al. 2002). Therefore, unemployment can be expected to be positively associated with earnings inequality. Unemployment rates are taken from the OECD (2014) Labour Force Statistics. ${ }^{11}$

\subsection{Method}

To explore the patterns in sectoral earnings inequality, the study relies on pooled time series cross-section regression analysis. To account for unobserved heterogeneity stemming from the fact that for a number of possibly relevant drivers of earnings inequality data are not available, the model contains unit fixed effects. Given the structure of our data with sectors in countries as our unit of observation, we include sector-by-country fixed effects. In the sensitivity analysis presented below, we also examine specifications with separate sector and country fixed effects and with random effects. Furthermore, we include wave fixed effects. The estimated equation of the model is:

$$
\mathrm{EI}_{\mathrm{ijt}}=\alpha_{0}+\beta_{0} \mathbf{x}_{\mathrm{ijt}}+\beta_{1} \mathbf{z}_{\mathrm{jt}}+\mu_{\mathrm{ij}}+\theta_{\mathrm{t}}+\varepsilon_{\mathrm{ijt}}
$$

where $i=$ sector, $j=$ country and $t=$ wave. EI denotes the level of earnings inequality. $\alpha_{0}$ is the intercept. The vector of independent variables at the sectoral level is denoted by $\mathbf{x}$, including variables for international trade, technological progress, and sectoral value added. The vector of independent variables at the country level is denoted by $\mathbf{z}$. This vector includes variables for the bargaining coverage rate, the level of wage coordination, the strictness of employment protection legislation, the political colour of the government and the unemployment rate. $\mu$ represents the sector-by-country fixed effects and $\theta$ are the wave fixed effects. The error term $\varepsilon$ is assumed to follow an i.i.d. normal distribution with mean zero. We estimate Eq. (1) using a fixed effects regression, with wave fixed effects and standard errors clustered at the country level.

\section{Empirical Analysis}

\subsection{Descriptive Statistics}

We start by showing descriptive statistics for our main sectoral variables for around 1985, 1995, and 2005. ${ }^{12}$ The developments in sectoral earnings inequality are shown in Fig. 1. The sectoral levels are pooled for all countries. ${ }^{13}$ We draw two general conclusions from Fig. 1.

First, there is substantial variation in levels of inequality across sectors. The most equally distributed sector, mining and quarrying, has a Gini coefficient of around 0.22 pooled across countries and years, whereas agriculture has a Gini coefficient of around 0.40. We find a similar large spread if we focus on a single country (results not shown here). To put this in perspective, we also calculate the Gini coefficient using the same

\footnotetext{
11 Summary statistics for all variables are provided in "Appendix 1" of Table 5. We provide additional summary statistics for the bargaining coverage across countries in Table 6.

12 We show information for around 2005 rather than 2007 to maximize data coverage-we do not have information for Sweden and Czech Republic for 2007 (see Table 1).

13 Figure 1 barely changes if we restrict the sample to the four countries for which we have data for all periods (Denmark, Germany, Finland, and the US). Inequality within the manufacturing of minerals in 1985 then becomes more pronounced.
} 


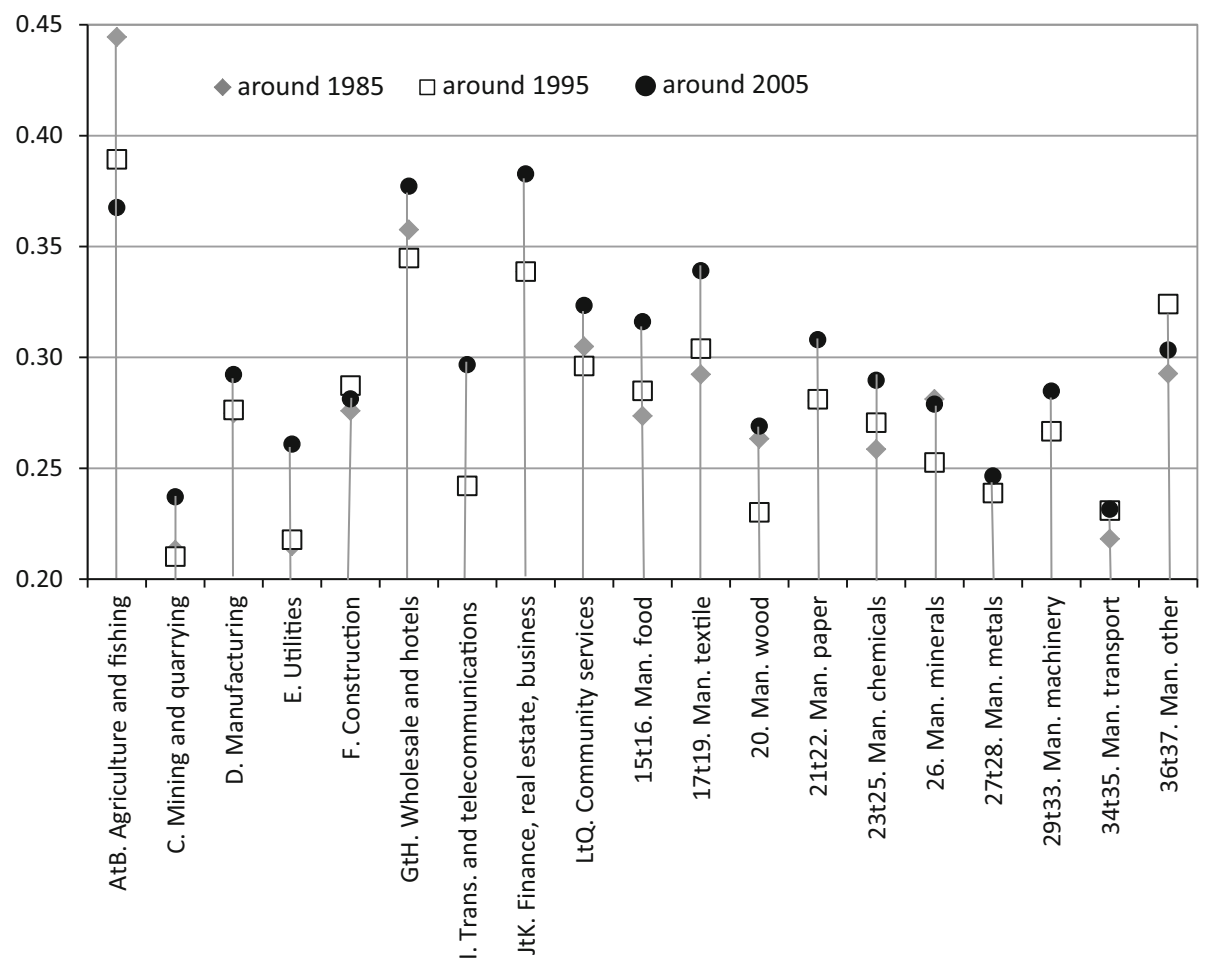

Fig. 1 Trends of sectoral earnings inequality over time. Note First order corrected Gini index, average for a sector and period across available countries. Source Wang et al. (2014) based on LIS micro data

income definition at the country level (results not shown here). The country with the highest level of inequality pooled over time is the US, with a Gini of around 0.40. Earnings are most equally distributed at the country level in Denmark with a Gini of around 0.26. The fact that there is on average as much spread in sectoral levels of inequality within countries, as there is in levels of country-level inequality, acknowledges the importance of a sectoral perspective for our understanding of earnings inequality.

A second conclusion is that sectoral earnings in general have become more dispersed over time. In 15 out of 19 sectors earnings were more dispersed in 2005 than around 1985 or 1995. In four sectors, in particular in agriculture which has the highest level of earnings inequality on average, the level of dispersion decreased over time. This general trend in rising levels of inequality across sectors seems to point to a common factor at the countrylevel that has contributed to rising levels of earnings inequality. Particularly interesting also is the comparison between the manufacturing sector, highly exposed to international trade, and the community sector, sheltered against international trade. Contrary to what we would expect from the literature, we see on average higher levels and a stronger increase of inequality in the sheltered community sector than in the manufacturing industry.

Table 2 shows the degree to which sectors are exposed to trade with all countries, trade with less developed countries, and technological change. With regard to the exposure to trade with all countries, there is considerable variation across sectors. The highest levels are found in the mining sector and the manufacturing sector. Within the manufacturing 
Table 2 Trends in international trade and technological change at the sectoral level

\begin{tabular}{|c|c|c|c|c|c|c|c|c|}
\hline & \multicolumn{3}{|c|}{$\begin{array}{l}\text { Trade in goods and } \\
\text { services with all } \\
\text { countries (\% sectoral } \\
\text { value added) }\end{array}$} & \multicolumn{2}{|c|}{$\begin{array}{l}\text { Trade in goods } \\
\text { and services } \\
\text { with all less } \\
\text { developed } \\
\text { countries (\% } \\
\text { sectoral value } \\
\text { added) }\end{array}$} & \multicolumn{3}{|c|}{$\begin{array}{l}\text { ICT capital } \\
\text { compensation (share } \\
\text { in sectoral value } \\
\text { added) }\end{array}$} \\
\hline & 1985 & 1995 & 2005 & 1995 & 2005 & 1985 & 1995 & 2005 \\
\hline \multicolumn{9}{|l|}{ Sectoral level } \\
\hline AtB. Agriculture & 55.4 & 54.4 & 74.3 & 4.2 & 6.2 & 0.01 & 0.01 & 0.01 \\
\hline C. Mining & 328.3 & 257.0 & 507.6 & 89.6 & 188.4 & 0.02 & 0.02 & 0.01 \\
\hline D. Manufacturing & 175.1 & 244.8 & 313.8 & 10.4 & 21.7 & 0.03 & 0.03 & 0.04 \\
\hline E. Utilities & 7.3 & 3.5 & 9.2 & - & - & 0.03 & 0.03 & 0.04 \\
\hline F. Construction & 5.8 & 8.9 & 5.7 & - & 1.4 & 0.00 & 0.01 & 0.01 \\
\hline GtH. Wholesale & 25.5 & 43.1 & 35.4 & - & 1.5 & 0.05 & 0.04 & 0.04 \\
\hline I. Transport and telecommunications & 38.3 & 45.1 & 72.0 & - & 1.2 & 0.06 & 0.07 & 0.10 \\
\hline JtK. Finance & 3.4 & 35.3 & 60.3 & - & 0.5 & 0.05 & 0.06 & 0.06 \\
\hline LtQ. Community & 4.7 & 3.4 & 2.1 & - & 0.0 & 0.02 & 0.02 & 0.02 \\
\hline \multicolumn{9}{|l|}{ Subsectoral level } \\
\hline 15t16. Man. food & 113.0 & 160.1 & 165.1 & 7.7 & 7.3 & 0.02 & 0.03 & 0.03 \\
\hline 17t19. Man. textile & 302.1 & 401.4 & 781.6 & 35.0 & 95.0 & 0.01 & 0.01 & 0.02 \\
\hline 20. Man. wood & 129.7 & 158.8 & 164.3 & 4.8 & 12.3 & 0.02 & 0.01 & 0.02 \\
\hline 21t22. Man. paper & 93.7 & 143.2 & 138.1 & 3.5 & 5.0 & 0.04 & 0.04 & 0.06 \\
\hline 23t25. Man. chemicals & 222.6 & 263.9 & 359.8 & 10.4 & 17.8 & 0.03 & 0.03 & 0.04 \\
\hline 26. Man. minerals & 72.1 & 99.0 & 128.4 & 3.5 & 8.1 & 0.03 & 0.02 & 0.02 \\
\hline 27t28. Man. metals & 157.5 & 207.4 & 236.5 & 8.8 & 16.1 & 0.01 & 0.02 & 0.03 \\
\hline 29t33. Man. machinery & 220.6 & 387.7 & 457.2 & 14.2 & 39.5 & 0.03 & 0.04 & 0.05 \\
\hline 34t35. Man. transport & 282.7 & 430.7 & 674.5 & 9.4 & 21.9 & 0.02 & 0.03 & 0.04 \\
\hline 36t37. Other man. & 155.2 & 183.9 & 255.3 & 16.2 & 38.7 & 0.02 & 0.02 & 0.02 \\
\hline Average & 71.5 & 77.3 & 120.0 & - & - & 0.03 & 0.03 & 0.04 \\
\hline
\end{tabular}

Source Import and export from OECD STAN, share of ICT in sectoral value added from EU-KLEMS

Information is pooled for countries for which data are available. 1985 data for trade with developing countries is not available

sector, the textile, the machinery and the transport sectors are the most exposed to international trade. Also the increase over time in international trade differs per sector. The largest increase took place in the manufacturing of textile and manufacturing of transport. In contrast, the amount of international trade barely rose in the utility sector.

With regard to trade with less developed countries, the highest sectoral exposure to this type of trade can be found in the mining sector, which is the same as for trade with all countries. The second-highest exposed sector is the textile sector. Most sectors became more exposure to trade with less developed countries over time.

Also for the levels and developments of exposure to technological change we can see differences between sectors. The starkest increases took place in the transport and telecommunications sector. Within the manufacturing sector, technology changed the most 
in the paper, metals, machinery and transport sectors. The ICT capital compensation decreased in the wholesale sector and in the manufacturing of minerals sector.

\subsection{Regression Results}

The results of the regressions are presented in Table 3 . The models indicate that the sectoral exposure to international trade with all countries is not significantly associated with sectoral earnings inequality. Hence, these results do not seem to provide evidence for the hypothesis that sectors more exposed to international trade have a more dispersed earnings distribution. Model 2 and Model 4 indicate a positive association between technological progress and sectoral earnings inequality. This result is in line with the hypothesis that skill-biased technological change leads to higher levels of earnings inequality. However, as will be discussed below, this result is not robust.

Interestingly, the bargaining coverage rate is negatively associated with sectoral earnings inequality. This corresponds to our hypothesis that bargaining coverage is negatively associated with earnings inequality. When more employees are covered by bargaining agreements, there is less variation in wages between workers. The unemployment rate is negatively associated with earnings inequality. Yet, when we add the other independent variables in Model 4, the coefficient for the unemployment rate is not significant anymore. Finally, we do not find significant associations for the sectoral value added, the level of

Table 3 Panel data regressions for earnings inequality within sectors

\begin{tabular}{|c|c|c|c|c|}
\hline & (1) & (2) & (3) & (4) \\
\hline Trade with all countries & $\begin{array}{l}0.003 \\
(0.210)\end{array}$ & & & $\begin{array}{l}0.003 \\
(0.201)\end{array}$ \\
\hline Technology & & $\begin{array}{l}41.401 * * \\
(0.046)\end{array}$ & & $\begin{array}{l}45.466 * * \\
(0.039)\end{array}$ \\
\hline Value added & $\begin{array}{l}2.000 \\
(0.182)\end{array}$ & $\begin{array}{l}1.171 \\
(0.379)\end{array}$ & $\begin{array}{l}0.811 \\
(0.341)\end{array}$ & $\begin{array}{l}1.131 \\
(0.359)\end{array}$ \\
\hline Bargaining coverage rate & & & $\begin{array}{l}-0.188^{* * * *} \\
(0.000)\end{array}$ & $\begin{array}{l}-0.185^{\text {**** }} \\
(0.000)\end{array}$ \\
\hline Wage coordination & & & $\begin{array}{l}-0.298 \\
(0.542)\end{array}$ & $\begin{array}{l}-0.117 \\
(0.810)\end{array}$ \\
\hline Employment protection & & & $\begin{array}{l}-1.208 \\
(0.320)\end{array}$ & $\begin{array}{l}-0.852 \\
(0.460)\end{array}$ \\
\hline Left government & & & $\begin{array}{l}-0.014 \\
(0.197)\end{array}$ & $\begin{array}{l}-0.012 \\
(0.212)\end{array}$ \\
\hline Unemployment rate & & & $\begin{array}{l}-0.204^{*} \\
(0.074)\end{array}$ & $\begin{array}{l}-0.185 \\
(0.111)\end{array}$ \\
\hline Constant & $\begin{array}{l}18.831 * * \\
(0.020)\end{array}$ & $\begin{array}{l}21.842 * * * \\
(0.006)\end{array}$ & $\begin{array}{l}41.361 * * * \\
(0.000)\end{array}$ & $\begin{array}{l}36.795 * * * \\
(0.001)\end{array}$ \\
\hline $\mathrm{N}$ & 588 & 588 & 588 & 588 \\
\hline Number of groups & 143 & 143 & 143 & 143 \\
\hline Adjusted $\mathrm{R}^{2}$ & 0.112 & 0.112 & 0.163 & 0.176 \\
\hline
\end{tabular}

Estimated using fixed effects regression with wave fixed effects and standard errors clustered at the country level

$p$ values in parentheses $* p<0.1 ; * * p<0.05 ; * * * p<0.01$ 
wage coordination, the strictness of employment protection legislation, and for the political ideology of governments.

Subsequently, we focus the analysis on trade with less developed countries. The results are presented in Table 4. Model 1 indicates that trade with less developed countries is positively associated with sectoral earnings inequality. Model 2 shows that this result holds when the other independent variables are added to the model. These results suggest that sectors more exposed to trade with less developed countries have a more dispersed earnings distribution.

As discussed above, for trade with less developed countries, fewer observations are available. This implies that the sample that we use in the analyses in Table 4 differs from the sample that we use in Table 3. This difference in samples could possibly affect the results. Therefore, we also run the regression specification of Model 4 in Table 3 with the sample of Table 4. The results are presented in Model 3 of Table 4. The results for international trade with all countries of Model 3 in Table 4 are highly comparable to the results for international trade with all countries of Model 4 in Table 3. This indicates that

Table 4 Earnings inequality and trade with less developed countries

\begin{tabular}{|c|c|c|c|}
\hline & $\begin{array}{l}\text { (4.1) } \\
\text { Trade with less developed } \\
\text { countries }\end{array}$ & $\begin{array}{l}(4.2) \\
\text { Trade with less developed } \\
\text { countries }\end{array}$ & $\begin{array}{l}\text { (4.3) } \\
\text { Country sample of } \\
\text { Model } 5\end{array}$ \\
\hline Trade with all countries & & & $\begin{array}{l}0.003 \\
(0.296)\end{array}$ \\
\hline $\begin{array}{l}\text { Trade with less developed } \\
\text { countries }\end{array}$ & $\begin{array}{l}0.009 * \\
(0.063)\end{array}$ & $\begin{array}{l}0.008 * \\
(0.097)\end{array}$ & \\
\hline Technology & & $\begin{array}{l}54.422 \\
(0.135)\end{array}$ & $\begin{array}{l}52.732 \\
(0.143)\end{array}$ \\
\hline Value added & $\begin{array}{l}0.520 \\
(0.634)\end{array}$ & $\begin{array}{l}-1.109 \\
(0.278)\end{array}$ & $\begin{array}{l}-0.890 \\
(0.462)\end{array}$ \\
\hline Bargaining coverage rate & & $\begin{array}{l}-0.228 * * * \\
(0.005)\end{array}$ & $\begin{array}{l}-0.210 * * * \\
(0.010)\end{array}$ \\
\hline Wage coordination & & $\begin{array}{l}-0.273 \\
(0.750)\end{array}$ & $\begin{array}{l}-0.157 \\
(0.872)\end{array}$ \\
\hline Employment protection & & $\begin{array}{l}-5.766 \\
(0.133)\end{array}$ & $\begin{array}{l}-5.515 \\
(0.182)\end{array}$ \\
\hline Left government & & $\begin{array}{l}-0.012 \\
(0.391)\end{array}$ & $\begin{array}{l}-0.008 \\
(0.545)\end{array}$ \\
\hline Unemployment rate & & $\begin{array}{l}-0.164 \\
(0.366)\end{array}$ & $\begin{array}{l}-0.214 \\
(0.242)\end{array}$ \\
\hline Constant & $\begin{array}{l}25.530 * * * \\
(0.001)\end{array}$ & $\begin{array}{l}59.560 * * * \\
(0.003)\end{array}$ & $\begin{array}{l}57.061 * * * \\
(0.009)\end{array}$ \\
\hline $\mathrm{N}$ & 120 & 120 & 120 \\
\hline Number of groups & 359 & 359 & 359 \\
\hline Adjusted $\mathrm{R}^{2}$ & 0.101 & 0.157 & 0.148 \\
\hline
\end{tabular}

Estimated using fixed effects regression with wave fixed effects and standard errors clustered at the country level

$p$ values in parentheses $* p<0.1 ; * * p<0.05 ; * * * p<0.01$ 
the results for trade with all countries are not affected by the different samples. In contrast, the results show that the coefficient technological change is not significant anymore and Model 3 of Table 4 suggests that this is the result of taking a different sample. The results for the other variables in Model 3 in Table 4 are comparable to the results of Model 4 in Table 3.

\subsection{Sensitivity Analyses}

To examine the robustness of our results, we perform a number of sensitivity analyses, the results of which are shown in "Appendix 2". First, we use an alternative indicator for international trade (Table 7). Instead of the sum of imports and exports, we include imports and net imports (imports minus exports) separately in the regression (as in Mahler 2004), again expressed as a percentage of sectoral value added. The results presented above are replicated, both for international trade with all countries and for trade with less developed countries. For net imports the results show a positive and significant association with earnings inequality.

Second, we examine the robustness of the results for technological change by including the second technological change indicator available in the EU-KLEMS dataset at the sectoral level, namely, the contribution of ICT capital to value added growth in percentage points (Table 8). All the results presented above are replicated.

As in other recent inequality studies (e.g. Michaels et al. 2014) we do not account for increased international capital mobility as another aspect of globalisation (Mahler 2004) in our regressions because of limited data availability. As sensitivity tests, we include sectoral data for total, inward, and outward foreign direct (FDI) investment positions (Table 9). We again find estimates in line with our main results. Including FDI does not affect the significance of trade with developing countries. In some models, we find positive and significant coefficients for the FDI variable. However, as we lose up to half of the number of observations, we do not prefer these models as our main estimations. ${ }^{14}$

Subsequently, we examine the dependence of the results on different specifications of the empirical model (Table 10). First, estimations without wave dummies produce comparable results for the main variables of interest. Second, instead of estimating a model with unit-fixed effects (sector-by-country pairs), we run a pooled cross-section OLS estimation with separate country and sector fixed effects (and wave effects). The results are in line with the results for our main models. Third, random-effects models yield results, which are in line with our main results.

Finally, we examine whether the results might be driven by developments in single sectors (presented in Tables 11 and 12). When we run the regressions and drop the sectors one by one, the results presented above are largely replicated. ${ }^{15}$

\footnotetext{
14 Moreover, FDI flows, which entail an even larger loss of data, are not significant (results available upon request).

15 When we omit the agriculture sector (AtB) and the manufacturing of minerals (26), technological change becomes insignificant, whereas it becomes significant at the $1 \%$ without mining $(\mathrm{C})$. Furthermore, trade with less developed countries becomes (borderline) insignificant when we leave out agriculture (AtB), manufacturing of food (15t16), chemicals (23t25), metals (27t28), transport (34t35), or construction (F), whilst it becomes significant at the $5 \%$ when leaving out mining (C) or manufacturing other (36t 37$)$.
} 


\section{Conclusions}

This study aims to contribute to our understanding of developments and drivers of earnings inequality by using newly assembled sectoral data for eight countries between 1984 and 2007. The data show a spread in levels of earnings inequality across sectors comparable to the spread in country-level earnings inequality across countries. This highlights the importance of a sectoral perspective for our understanding of inequality in the crosssectional dimension. Interestingly, our sectoral dataset also reveals that sectoral earnings have generally become more unequal over time. This then suggests that a more common factor is at work in pushing inequalities in the time series dimension.

With our sectoral data, we are able to examine drivers of earnings inequality at a more detailed level based on longitudinal data across 8 OECD countries. The results provide only limited support for the argument that international trade leads to higher levels of earnings inequality. When we focus the analysis on trade with less developed countriesrather than the sectoral exposure to international trade in general-we find a positive association between trade and earnings inequality. This is in line with the argument that when developed countries engage into trade with less developed countries, mainly the lowskilled employees suffer from the increased competition (e.g., Burgoon 2001; Thewissen and Van Vliet 2015). As such, these findings are in line with and complement the findings of other sectoral studies on earnings inequality that only include two time periods and focus on particular determinants of earnings inequality (Mahler et al. 1999; OECD 2011a; Michaels et al. 2014).

With regard to technological change, our findings provide mixed evidence for the hypothesis that skill-biased technological change increases earnings inequality. Only for the larger sample for which we have data on trade with all countries, we find significant positive associations between technological change and earnings inequality. The mixed finding does not seem to be in line with the sectoral evidence reported by Michaels et al. (2014), who find a consistently significant effect. However, Michaels et al. focus on polarisation in skill demand rather than earnings inequality. Hence, a relevant question for future research is in what way polarisation in skill demand seeps through to earnings inequality at the sectoral level.

Interestingly, our results bring back labour market institutions at the country level as important drivers of earnings inequality. This corresponds with the fact that our sectoral data reveal a more general trend towards rising inequality at the sectoral level over time. The bargaining coverage rate is consistently found to be negatively associated with sectoral earnings inequality, which corresponds to the hypothesis that waning trade union power is an explanation for rising inequality (e.g., Koeniger et al. 2007). When fewer employees are covered by bargaining agreements, there is more variation in wages between workers. To obtain an even more fine-grained understanding of how the declining influence of trade unions affects sectoral earnings inequality, sectoral data on bargaining coverage rates would be needed. Unfortunately, such data are currently not available with sufficient detail for our set of countries over time (e.g. Pinto and Beckfield 2011; Kristal 2013). More generally, our results may be affected by the fact that for many variables, adequate indicators at the sectoral level for analyses across countries and over time are not available. Even though we used conventional-and the currently best available-measures for technological change, these measures might only be limited proxies for the developments of skill-biased technological change. 
Acknowledgements We thank the editor, two anonymous reviewers, Ben Ansell, Jason, Beckfield, Koen Caminada, Janet Gornick, Kees Goudswaard, Torben Iversen, and Brian Nolan for their helpful comments. We gratefully acknowledge financial support from China Postdoctoral Science Foundation [grant number 2016M591645] and Shanghai Pujiang Program. The usual disclaimer applies.

Open Access This article is distributed under the terms of the Creative Commons Attribution 4.0 International License (http://creativecommons.org/licenses/by/4.0/), which permits unrestricted use, distribution, and reproduction in any medium, provided you give appropriate credit to the original author(s) and the source, provide a link to the Creative Commons license, and indicate if changes were made.

\section{Appendix 1: Descriptive statistics}

See Tables 5 and 6.

Table 5 Summary statistics

\begin{tabular}{|c|c|c|c|c|c|}
\hline Variable & Observations & Mean & SD & $\begin{array}{l}\text { Minimum } \\
\text { value }\end{array}$ & $\begin{array}{l}\text { Maximum } \\
\text { value }\end{array}$ \\
\hline $\begin{array}{l}\text { Earnings inequality (first order corrected } \\
\text { Gini index) }\end{array}$ & 588 & 29.37 & 7.58 & 8.28 & 59.71 \\
\hline $\begin{array}{l}\text { Trade with all countries ( } \% \text { of sectoral value } \\
\text { added) }\end{array}$ & 588 & 196.94 & 265.88 & 0 & 2388.31 \\
\hline $\begin{array}{l}\text { Trade with developing countries (\% sectoral } \\
\text { value added) }\end{array}$ & 359 & 32.27 & 102.54 & 0 & 1317.21 \\
\hline $\begin{array}{l}\text { Technology (ICT capital compensation as a } \\
\text { share of sectoral value added) }\end{array}$ & 588 & 0.03 & 0.03 & 0 & 0.19 \\
\hline $\begin{array}{l}\text { Value added (ln of sectoral volume indices, } \\
1995=100)\end{array}$ & 588 & 4.70 & 0.31 & 3.91 & 6.42 \\
\hline Bargaining coverage rate & 588 & 60.98 & 27.59 & 13.30 & 94.00 \\
\hline Wage coordination & 588 & 3.00 & 1.43 & 1.00 & 5.00 \\
\hline Employment protection index & 588 & 1.88 & 0.96 & 0.26 & 3.31 \\
\hline Left government (share of cabinet seats) & 588 & 35.67 & 40.07 & 0 & 100 \\
\hline Unemployment rate & 588 & 6.93 & 2.52 & 3.80 & 15.45 \\
\hline $\begin{array}{l}\text { Imports from all countries ( } \% \text { of sectoral } \\
\text { value added) }\end{array}$ & 588 & 117.79 & 201.44 & 0.00 & 1668.86 \\
\hline $\begin{array}{l}\text { Net imports from all countries ( } \% \text { of sectoral } \\
\text { value added) }\end{array}$ & 588 & 38.64 & 173.00 & -260.45 & 1622.77 \\
\hline $\begin{array}{l}\text { Imports from developing countries ( } \% \text { of } \\
\text { sectoral value added) }\end{array}$ & 373 & 25.92 & 99.11 & 0.00 & 1310.35 \\
\hline $\begin{array}{l}\text { Net imports from developing countries ( } \% \text { of } \\
\text { sectoral value added) }\end{array}$ & 359 & 20.75 & 100.63 & -107.85 & 1303.50 \\
\hline $\begin{array}{l}\text { The contribution of ICT capital to value } \\
\text { added growth (ppt) }\end{array}$ & 550 & 0.34 & 0.43 & -1.27 & 4.29 \\
\hline $\begin{array}{l}\text { Total FDI positions ( } \% \text { of sectoral value } \\
\text { added) }\end{array}$ & 320 & 172.16 & 1256.70 & -0.76 & $16,623.62$ \\
\hline $\begin{array}{l}\text { Inward FDI positions ( } \% \text { of sectoral value } \\
\text { added) }\end{array}$ & 320 & 74.39 & 556.93 & 0.00 & 9284.49 \\
\hline $\begin{array}{l}\text { Outward FDI positions ( } \% \text { of sectoral value } \\
\text { added) }\end{array}$ & 320 & 97.77 & 797.06 & -1.88 & $12,988.93$ \\
\hline
\end{tabular}


Table 6 Trends in bargaining coverage across countries

\begin{tabular}{lllllll}
\hline Country & \multicolumn{6}{l}{ Bargaining coverage } \\
\cline { 2 - 7 } & Wave 1 & Wave 2 & Wave 3 & Wave 4 & Wave 5 & Wave 6 \\
\hline Czech Republic & & & 51.9 & & 35.9 & \\
Denmark & 83.4 & 84 & 84 & 83.25 & 85 & 85 \\
Finland & 81 & 85 & 85.25 & 86.5 & 88.3 & 89.02 \\
Germany & 85 & 85 & 77.8 & 68.9 & 65.75 & 64.05 \\
Ireland & & & 60.0 & & 50.4 & 44.0 \\
Sweden & 85.5 & 89 & & 94 & 94 & \\
UK & 62.0 & & & 36.1 & 34.7 & 34.6 \\
US & 19.9 & 18.2 & 17.4 & 14.9 & 13.8 & 13.3 \\
\hline
\end{tabular}

Source ICTWSS 4.0 (Visser 2013), except for Ireland, which is taken from ICTWSS 3.0 and linearly interpolated (see also footnote 10 in the main text)

The bargaining coverage rate is defined as the proportion of employees covered by wage bargaining agreements. The data cover the following years

Wave 1: Denmark (1987), Finland (1987), Germany (1984), Sweden (1987), UK (1986) and US (1986)

Wave 2: Denmark (1992), Finland (1991), Germany (1989), Sweden (1992) and US (1991)

Wave 3: Czech Republic (1996), Denmark (1995), Finland (1995), Germany (1994), Ireland (1995) and US (1994)

Wave 4: Denmark (2000), Finland (2000), Germany (2000), Sweden (2000), UK (1999) and US (2000)

Wave 5: Czech Republic (2004), Denmark (2004), Finland (2004), Germany (2004), Ireland (2004), Sweden (2005), UK (2004) and US (2004)

Wave 6: Denmark (2007), Finland (2007), Germany (2007), Ireland (2007), UK (2007) and US (2007)

\section{Appendix 2: Sensitivity Analyses}

See Tables 7, 8, 9, 10, 11 and 12.

Table 7 Different trade indicators

\begin{tabular}{lllllll}
\hline & $(7.1)$ & $(7.2)$ & $(7.3)$ & $(7.4)$ & $(7.5)$ & $(7.6)$ \\
\hline Trade with all countries & 0.003 & & & & & \\
& $(0.201)$ & & & & \\
Imports with all & & 0.004 & & & & \\
$\quad$ countries & & $(0.107)$ & & & & \\
$\begin{array}{l}\text { Net Imports with all } \\
\quad \text { countries }\end{array}$ & & $0.005^{* *}$ & & & \\
Trade with LDCs & & $(0.047)$ & & $0.008^{*}$ & & \\
& & & $(0.097)$ & & \\
Imports with LDCs & & & & & $0.010^{* *}$ & \\
& & & & & & \\
Net Imports with LDCs & & & & & & \\
& & & & & & \\
Technology & $45.466^{* *}$ & $45.321^{* *}$ & $43.955^{* *}$ & 54.422 & $61.518^{*}$ & 54.378 \\
& $(0.039)$ & $(0.042)$ & $(0.046)$ & $(0.135)$ & $(0.088)$ & $(0.133)$ \\
Value added & 1.131 & 1.288 & 1.185 & -1.109 & -0.317 & -1.173 \\
& $(0.359)$ & $(0.323)$ & $(0.306)$ & $(0.278)$ & $(0.750)$ & $(0.252)$ \\
\hline
\end{tabular}


Table 7 continued

\begin{tabular}{lllllll}
\hline & $(7.1)$ & $(7.2)$ & $(7.3)$ & $(7.4)$ & $(7.5)$ & $(7.6)$ \\
\hline Bargaining coverage & $-0.185^{* * *}$ & $-0.181 * * *$ & $-0.177 * * *$ & $-0.228^{* * *}$ & $-0.243^{* * *}$ & $-0.224 * * *$ \\
$\quad$ rate & $(0.000)$ & $(0.000)$ & $(0.001)$ & $(0.005)$ & $(0.002)$ & $(0.005)$ \\
Wage coordination & -0.117 & -0.107 & -0.134 & -0.273 & -0.243 & -0.266 \\
& $(0.810)$ & $(0.826)$ & $(0.774)$ & $(0.750)$ & $(0.715)$ & $(0.765)$ \\
Employment protection & -0.852 & -0.654 & -0.590 & -5.766 & -3.440 & -5.783 \\
& $(0.460)$ & $(0.569)$ & $(0.617)$ & $(0.133)$ & $(0.260)$ & $(0.142)$ \\
Left government & -0.012 & -0.011 & -0.011 & -0.012 & -0.017 & -0.011 \\
& $(0.212)$ & $(0.213)$ & $(0.215)$ & $(0.391)$ & $(0.191)$ & $(0.434)$ \\
Unemployment rate & -0.185 & -0.178 & -0.174 & -0.164 & -0.079 & -0.182 \\
& $(0.111)$ & $(0.129)$ & $(0.134)$ & $(0.366)$ & $(0.574)$ & $(0.317)$ \\
Constant & $36.795 * * *$ & $35.354 * * *$ & $35.744 * * *$ & $59.560 * * *$ & $51.208 * * *$ & $59.867 * * *$ \\
& $(0.001)$ & $(0.002)$ & $(0.001)$ & $(0.003)$ & $(0.002)$ & $(0.003)$ \\
$\mathrm{N}$ & 588 & 588 & 588 & 359 & 373 & 359 \\
Adjusted $\mathrm{R}^{2}$ & 0.176 & 0.180 & 0.181 & 0.157 & 0.127 & 0.153 \\
\hline
\end{tabular}

$p$ values in parentheses $* p<0.1 ; * * p<0.05$; *** $p<0.01$

Table 8 Different indicator for technological progress

\begin{tabular}{|c|c|c|}
\hline & $(8.1)$ & $(8.2)$ \\
\hline Trade with all countries & $\begin{array}{l}0.003 \\
(0.201)\end{array}$ & $\begin{array}{l}0.002 \\
(0.233)\end{array}$ \\
\hline Technology (ICT capital compensation as share of sectoral value added) & $\begin{array}{l}45.466 * * \\
(0.039)\end{array}$ & \\
\hline $\begin{array}{l}\text { Technology (contribution of ICT capital to value added growth in percentage } \\
\text { points) }\end{array}$ & & $\begin{array}{l}0.697 * * \\
(0.022)\end{array}$ \\
\hline Value added & $\begin{array}{l}1.131 \\
(0.359)\end{array}$ & $\begin{array}{l}1.191 \\
(0.347)\end{array}$ \\
\hline Bargaining coverage rate & $\begin{array}{l}-0.185^{* * * *} \\
(0.000)\end{array}$ & $\begin{array}{l}-0.196^{* * *} \\
(0.001)\end{array}$ \\
\hline Wage coordination & $\begin{array}{l}-0.117 \\
(0.810)\end{array}$ & $\begin{array}{l}-0.210 \\
(0.689)\end{array}$ \\
\hline Employment protection & $\begin{array}{l}-0.852 \\
(0.460)\end{array}$ & $\begin{array}{l}-0.438 \\
(0.735)\end{array}$ \\
\hline Left government & $\begin{array}{l}-0.012 \\
(0.212)\end{array}$ & $\begin{array}{l}-0.015 \\
(0.214)\end{array}$ \\
\hline Unemployment rate & $\begin{array}{l}-0.185 \\
(0.111)\end{array}$ & $\begin{array}{l}-0.183 \\
(0.194)\end{array}$ \\
\hline Constant & $\begin{array}{l}36.795 * * * \\
(0.001)\end{array}$ & $\begin{array}{l}37.178 \text { *** } \\
(0.002)\end{array}$ \\
\hline $\mathrm{N}$ & 588 & 558 \\
\hline Adjusted $\mathrm{R}^{2}$ & 0.176 & 0.188 \\
\hline
\end{tabular}

$p$ values in parentheses $* p<0.1 ; * * p<0.05 ; * * * p<0.01$ 


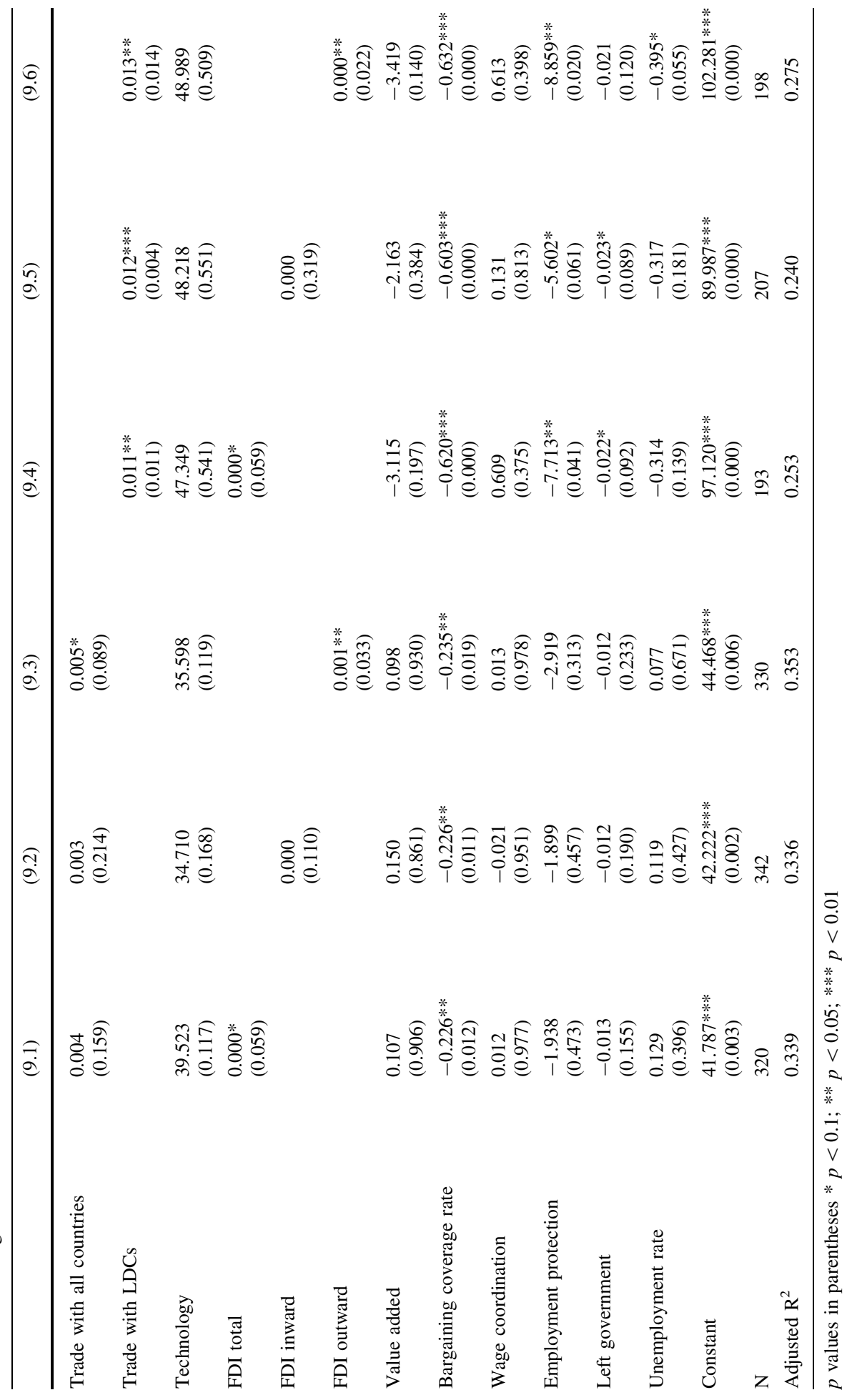




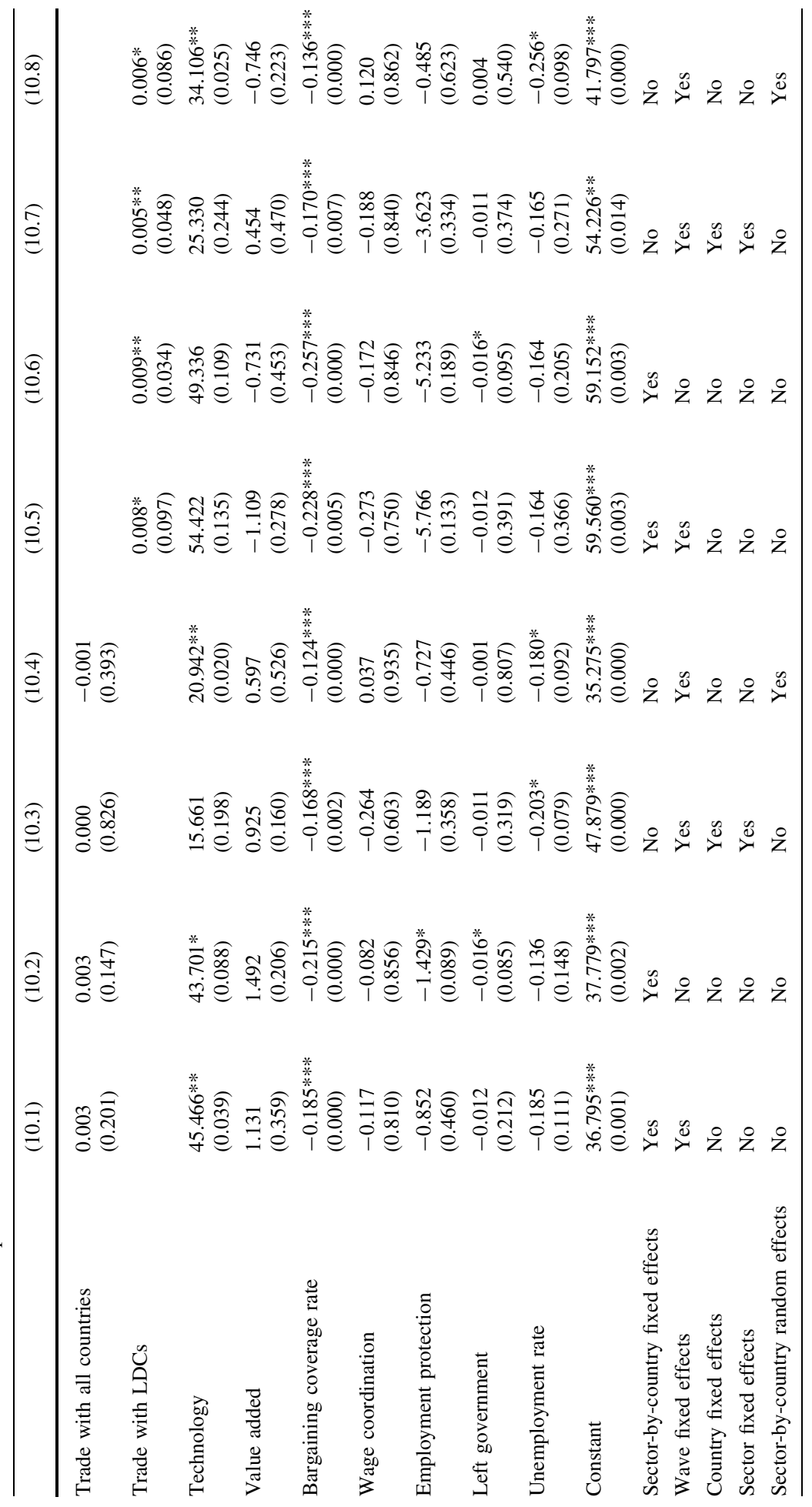




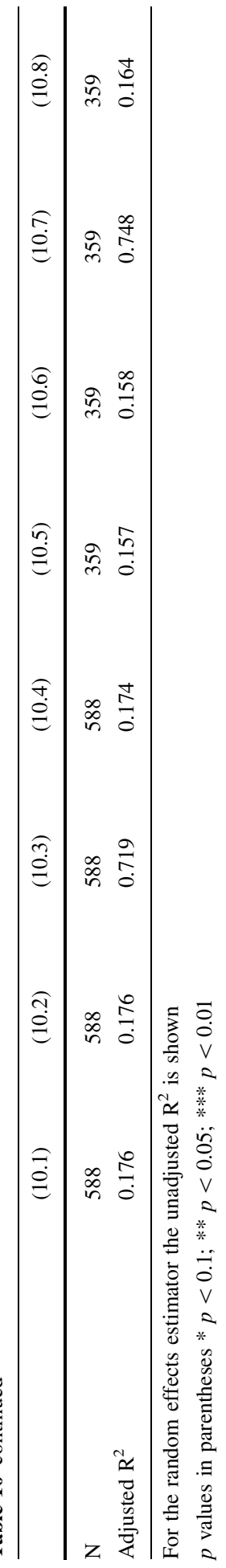




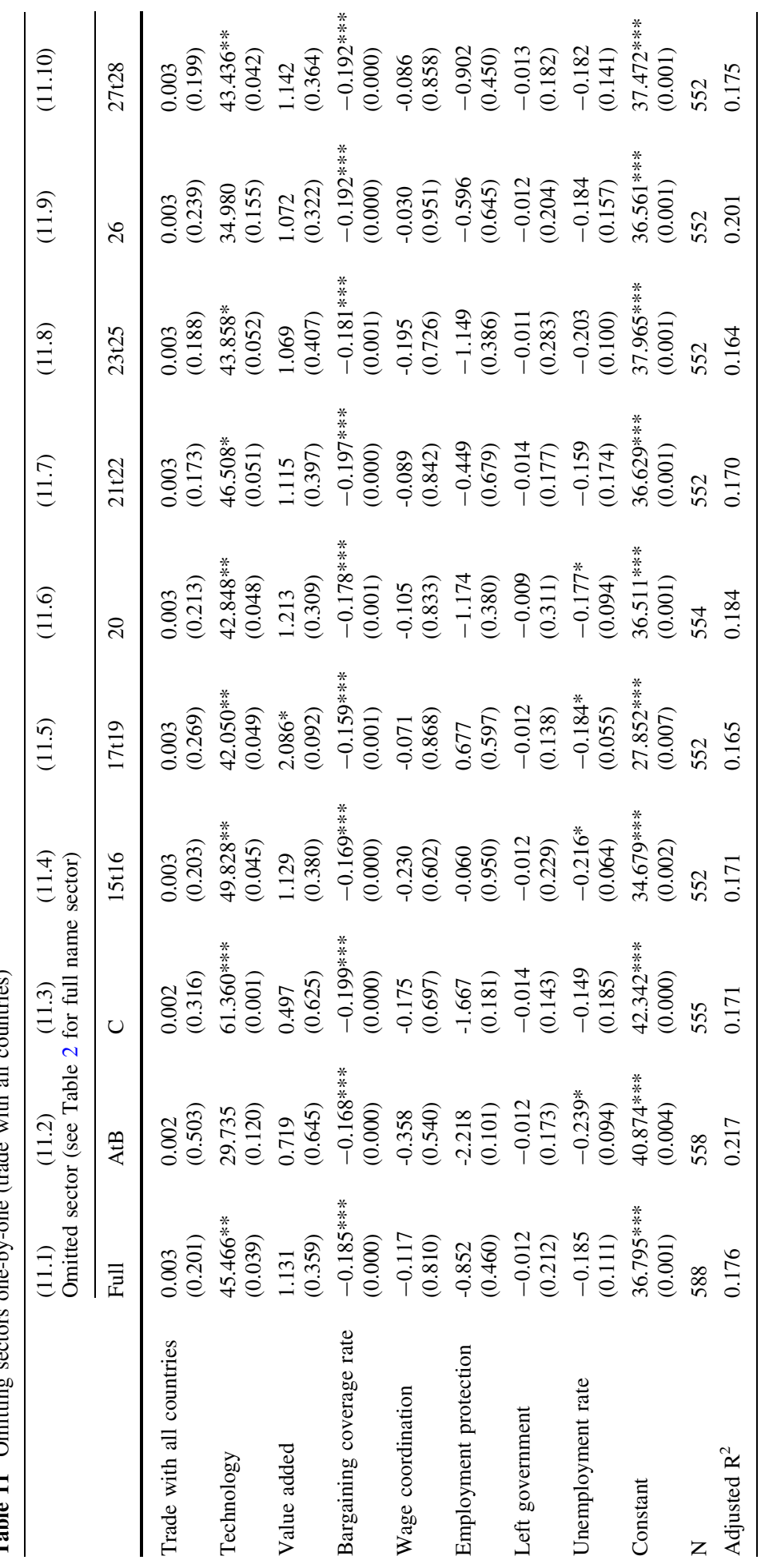




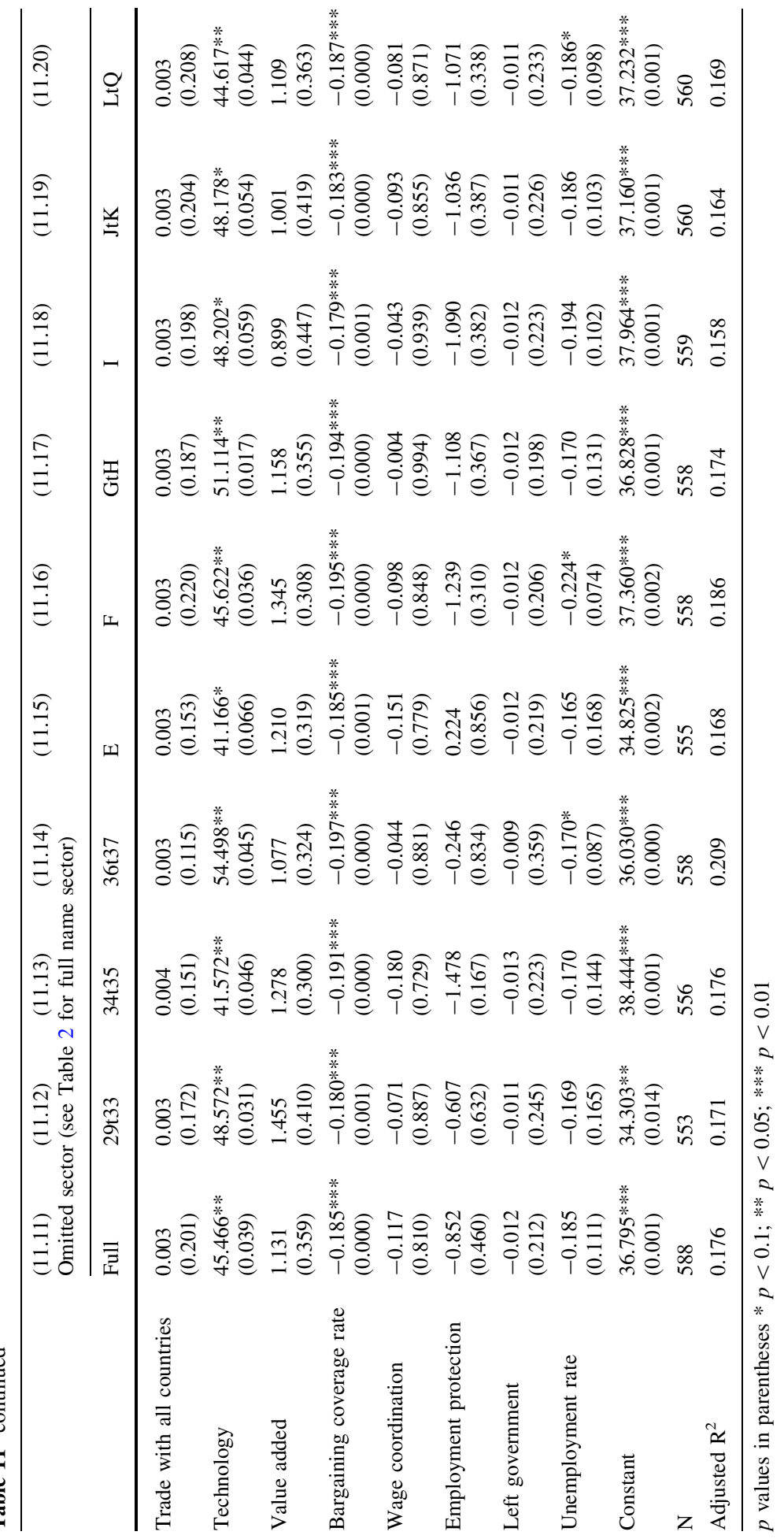




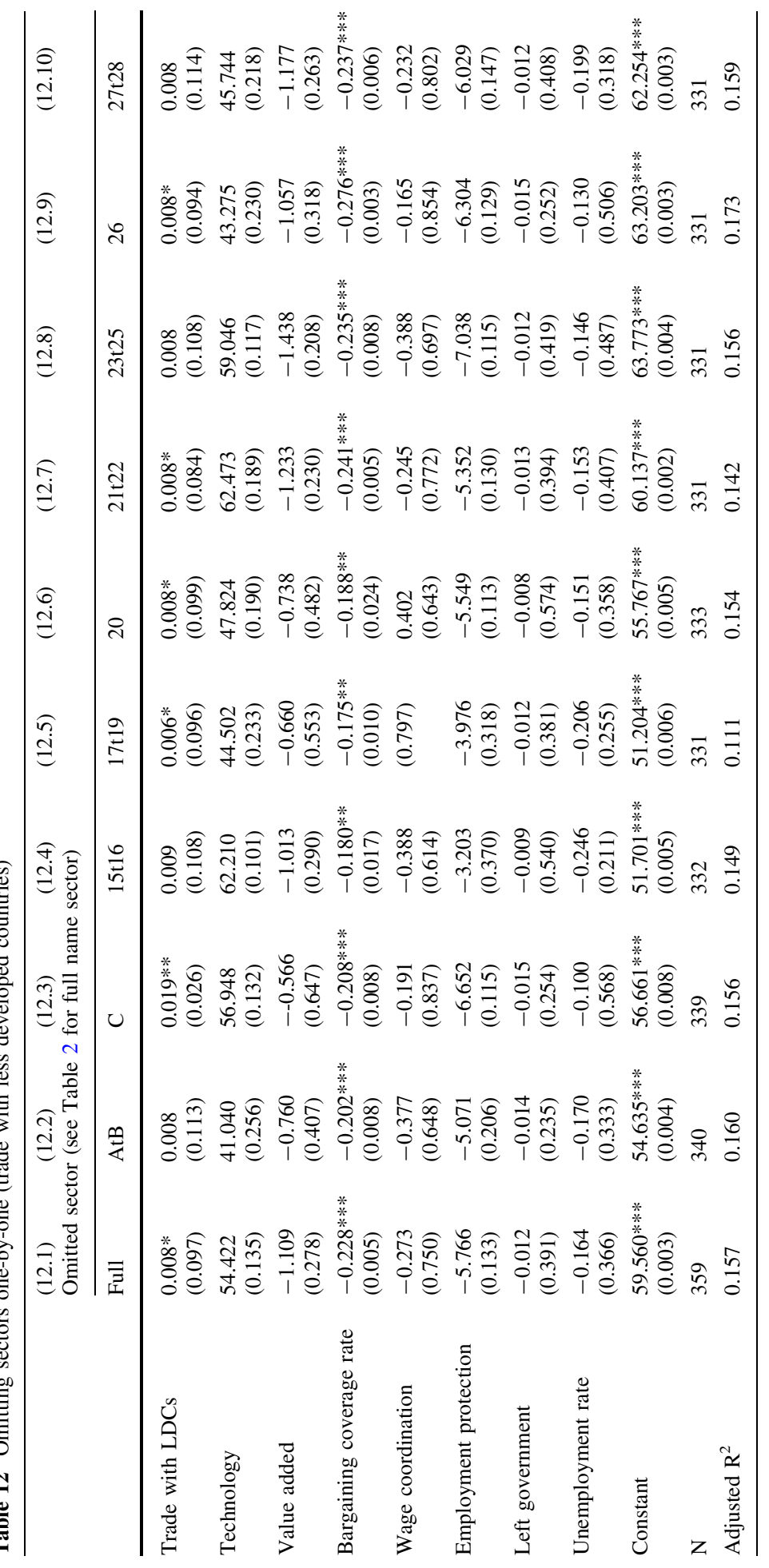




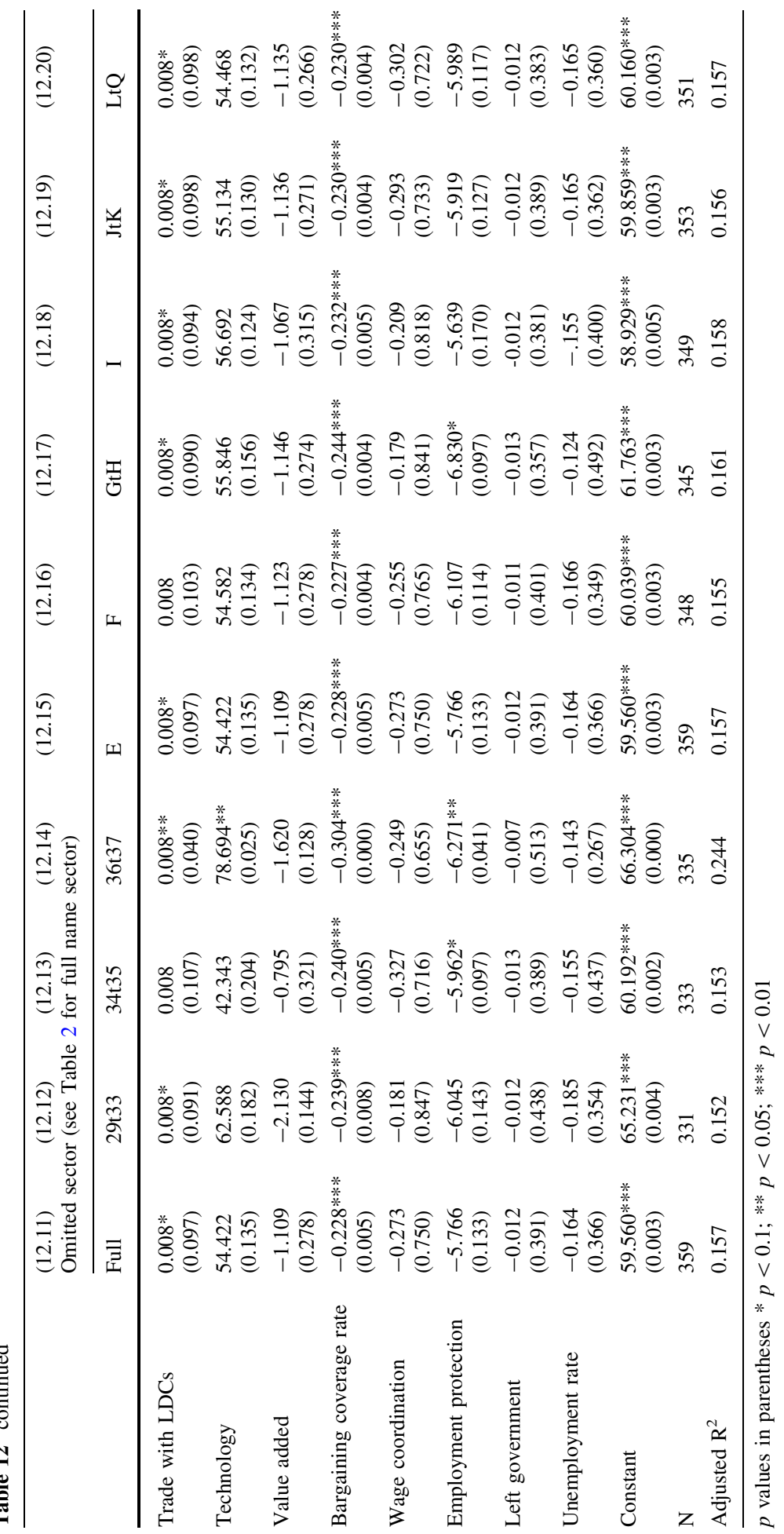




\section{References}

Alderson, A., Beckfield, J., \& Nielsen, F. (2005). Exactly how has income inequality changed? Patterns of distributional change in core societies. International Journal of Comparative Sociology, 46(5-6), 405-423.

Alderson, A., \& Doran, K. (2013). How has income inequality grown: The reshaping of the income distribution in LIS countries. In J. Gornick \& M. Jäntti (Eds.), Income inequality: Economic disparities and the middle class in affluent countries (pp. 51-74). Stanford CA: Stanford University Press.

Alderson, A., \& Nielsen, F. (2002). Globalization and the great U-turn: income inequality trends in 16 OECD countries. American Journal of Sociology, 107(5), 1244-1299.

Armingeon, K., Knopfel, L., Weisstanner, D., \& Engler, S. (2012). Comparative political data set III 1990-2012. Bern: University of Bern.

Atkinson, A. (2003). Income inequality in OECD countries: data and explanations. CESifo Economic Studies, 49(4), 479-513.

Autor, D., Levy, F., \& Murnane, R. (2003). The skill content of recent technological change: an empirical exploration. The Quarterly Journal of Economics, 118(4), 1279-1333.

Brandolini, A., \& Smeeding, T. (2009). Income inequality in richer and OECD countries. In W. Salverda, B. Nolan, \& T. Smeeding (Eds.), The Oxford handbook of economic inequality (pp. 71-100). Oxford: Oxford University Press.

Burgoon, B. (2001). Globalization and welfare compensation: disentangling the ties that bind. International Organization, 55(3), 509-551.

Christensen, D., \& Wibbels, E. (2013). Labor standards, labor endowments, and the evolution of inequality. International Studies Quarterly, 58(2), 362-379.

Deltas, G. (2003). The small-sample bias of the Gini coefficient: results and implications for empirical research. The Review of Economics and Statistics, 85(1), 226-234.

Estevez-Abe, M., Iversen, T., \& Soskice, D. (2001). Social protection and the formation of skills: A reinterpretation of the welfare state. In P. Hall \& D. Soskice (Eds.), Varieties of capitalism: The institutional foundations of comparative advantage (pp. 145-183). Oxford: Oxford University Press.

EU-KLEMS (2011). Growth and productivity accounts: March update. http://www.euklems.net/.

Freeman, R. B. (1991). How much has de-unionisation contributed to the rise in male earnings inequality? NBER Working Paper no. 3826.

Goldin, C., \& Katz, L. (2008). The race between education and technology. Cambridge: Harvard University Press.

Gornick, J., \& Jäntti, M. (Eds.). (2013). Income inequality: Economic disparities and the middle class in affluent countries. California: Stanford University Press.

Harrison, A., McLaren, J., \& McMillan, M. (2011). Recent perspectives on trade and inequality. Annual Review of Economics, 3(1), 261-289.

Hays, J. (2009). Globalization and the new politics of embedded liberalism. Oxford University Press.

Hellier, J., \& Chusseau, N. (Eds.). (2013). Growing income inequalities: Economic analyses. New York: Palgrave Macmillan.

Huber, E., \& Stephens, J. (2014). Income inequality and redistribution in post-industrial democracies: Demographic, economic and political determinants. Socio-Economic Review, 12(2), 245-267.

Immervoll, H., \& Richardson, L. (2011). Redistribution policy and inequality reduction in OECD countries: What has changed in two decades? OECD Working Paper no. 122.

Iversen, T., \& Soskice, D. (2013). A political-institutional model of competitiveness and the international division of labor. In A. Wren (Ed.), The political economy of the service transition (pp. 73-107). Oxford: Oxford University Press.

Kenworthy, L. (2001). Wage-setting measures: A survey and assessment. World Politics, 54(1), 57-98.

Kenworthy, L., \& Pontusson, J. (2005). Rising inequality and the politics of redistribution in affluent countries. Perspectives on Politics, 3(3), 449-471.

Koeniger, W., Leonardi, M., \& Nunziata, L. (2007). Labor market institutions and wage inequality. Industrial and Labor Relations Review, 60(3), 340-356.

Kristal, T. (2013). The capitalist machine: computerization, workers' power, and the decline in labor's share within U.S. industries. American Sociological Review, 78(3), 361-389.

Lindbeck, A., \& Snower, D. (2001). Insiders versus outsiders. The Journal of Economic Perspectives, 15(1), $165-188$.

LIS. (2013). Luxembourg income study database. www.lisdatacenter.org. Accessed 1 June 2013.

Mahler, V. (2004). Economic globalization, domestic politics, and income inequality in the developed countries: a cross-national study. Comparative Political Studies, 37(9), 1025-1053. 
Mahler, V., Jesuit, D., \& Roscoe, D. (1999). Exploring the impact of trade and investment on income inequality: a cross-national sectoral analysis of the developed countries. Comparative Political Studies, 32(3), 363-395.

Martin, C., \& Swank, D. (2012). The political construction of business interests: Coordination, growth, and equality. Cambridge University Press.

Michaels, G., Natraj, A., \& Van Reenen, J. (2014). Has ICT polarized skill demand? Evidence from eleven countries over 25 years. Review of Economics and Statistics, 96(1), 60-77.

Mortensen, D., \& Pissarides, C. (1999). New developments in models of search in the labor market. In O. Ashenfelter \& D. Card (Eds.), Handbook of labor economics (pp. 2567-2627). Amsterdam: Elsevier.

OECD. (2002). EBOPS Trade in services dataset. Paris: OECD.

OECD. (2009). Employment database. Paris: OECD.

OECD. (2011a). Divided we stand: Why inequality keeps rising. Paris: OECD.

OECD. (2011b). STAN structural analysis database. Paris: OECD.

OECD. (2014). Labour force statistics. Paris: OECD.

OECD. (2016). STAN bilateral database. Paris: OECD.

Oesch, D. (2013). Occupational change in Europe: How technology \& education transform the job structure. Oxford: Oxford University Press.

Oliver, R. (2008). Diverging developments in wage inequality: which institutions matter? Comparative Political Studies, 41(12), 1551-1582.

Pinto, S., \& Beckfield, J. (2011). Organized labor in Europe, 1960-2006: persistent diversity and shared decline. Research in the Sociology of Work, 22(2), 153-179.

Pontusson, J., Rueda, D., \& Way, C. (2002). Comparative political economy of wage distribution: the role of partisanship and labour market institutions. British Journal of Political Science, 32(2), 281-308.

Rueda, D. (2007). Social democracy inside out: Partisanship and labor market policy in advanced industrialized democracies. New York: Oxford University Press.

Rueda, D., \& Pontusson, J. (2000). Wage inequality and varieties of capitalism. World Politics, 52(3), 350-383.

Samuelson, P. (1971). Ohlin was Right. Swedish Journal of Economics, 73(4), 365-384.

Sirgy, M. J., Lee, D.-J., Miller, C., Littlefield, J. E., \& Atay, E. G. (2007). The impact of imports and exports on a country's quality of life. Social Indicators Research, 83, 245-281.

Swank, D. (2015). The political foundations of redistribution in post-industrial democracies. LIS Working Paper Series no. 653.

Thewissen, S., \& Van Vliet, O. (2015). Competing with the Dragon: Employment and wage effects of Chinese trade competition in 17 sectors across 18 OECD countries. INET Oxford Working Paper no. 2015-08.

Thewissen, S., Wang, C., \& Van Vliet, O. (2013). Sectoral trends in earnings inequality and employment: International trade, skill-biased technological change, or labour market institutions? LIS Working Paper Series no. 595.

Visser, J. (2013) ICTWSS: Database on institutional characteristics of trade unions, wage setting, state intervention and social pacts in 34 countries between 1960 and 2012 version 4. http://www.uva-aias. net $/ 208$.

Wallerstein, M. (1999). Wage setting institutions and pay inequality in advanced industrial societies. American Journal of Political Science, 43(3), 649-680.

Walter, S. (2010). Globalization and the Welfare State: testing the Microfoundations of the Compensation Hypothesis. International Studies Quarterly, 54, 403-426.

Wang, C., Thewissen, S., \& Van Vliet, O. (2014). Leiden LIS sectoral income inequality dataset version 1.1. http://www.law.leidenuniv.nl/org/fisceco/economie/hervormingsz/leidenlissectoralincomeinequalityda taset.html. Accessed 1 Mar 2014.

Western, B., \& Rosenfeld, J. (2011). Unions, Norms, and the Rise in U.S. Wage Inequality. American Sociological Review, 76(4), 513-537.

World Bank. (2013). World development indicators. http://data.worldbank.org/data-catalog/worlddevelopment-indicators/wdi-2012. Accessed 1 March 2013.

Wren, A. (2013). Introduction: The political economy of post-industrial societies. In A. Wren (Ed.), The political economy of the service transition (pp. 1-70). Oxford: Oxford University Press. 